MaŁgorzata ChojaK

ORCID 0000-0002-7558-7630

Uniwersytet Marii Curie-Skłodowskiej

$w$ Lublinie

\title{
NEUROPEDAGOGIKA WŚRÓD DYSCYPLIN NAUKOWYCH - PRÓBA DOPRECYZOWANIA NAZEWNICTWA
}

\begin{abstract}
AвSTRACT. Chojak Małgorzata, Neuropedagogika wśród dyscyplin naukowych - próba doprecyzowania nazewnictwa [Neuropedagogy Among Scientific Disciplines - an Attempt to Clarify Terminology]. Studia Edukacyjne nr 56, 2020, Poznań 2020, pp. 369-384. Adam Mickiewicz University Press. ISSN 1233-6688. DOI: $10.14746 /$ se.2020.56.20
\end{abstract}

In the last two decades, more and more publications pedagogical and psychological referring to research in the field of neurobiology. They appear in them new concepts and names of new disciplines such as neuropedagogy, neurodidactics or educational neuroscience and neuropsychology education. The US, the UK and Canada have attempted to standardize terminology and to clarify the scope of research across disciplines. This publication is not only an attempt to present the theoretical concept of the origin and interrelationships of newly established disciplines based on international scientific sources. The author has decided to embed analyses on the specifics of Polish terms to propose names for an interesting and new field known as Mind, Brain and Education (MBE).

Key worlds: neuropedagogy, neuroeducation, brain, MBE

W ostatnim dziesięcioleciu powstaje coraz więcej publikacji pedagogicznych i psychologicznych odwołujących się do badań z dziedziny neurobiologii. Wynika to $\mathrm{w}$ dużej mierze $\mathrm{z}$ rosnącej świadomości faktu, iż bez zastosowania wiedzy pochodzącej z badań neurologicznych nie można w pełni zrozumieć procesu uczenia się i nauczania oraz różnych jego zaburzeńn

${ }^{1}$ U. Goswami, Principles of Learning, Implications for Teaching: A Cognitive Neuroscience Perspective, Journal of Philosophy of Education, 2008, 42, 3-4; T. Tokuhama-Espinosa, The new science of teaching and learning: Using the best of mind, brain, and education science in the classroom, New York 2010; taże, Mind, Brain, and Education Science: The new brain-based learning, New York 2010; taże, A BRIEF HISTORY OF THE SCIENCE OF LEARNING: Part 2 (1970s-present), 2011 [on line] http://education.jhu.edu/PD/newhorizons/Journals/Winter2011/Tokuhama5; P. Howard- 
Zainteresowanie psychologów i pedagogów wynikami obiektywnych oraz coraz dokładniejszych badań z zakresu neuronauk wydaje się naturalną konsekwencją wobec narastającego kryzysu systemu edukacji oraz rosnących oczekiwań ze strony rodziców czy nauczycieli dotyczących efektywności podejmowanych działań. W związku $\mathrm{z}$ tym, w publikacjach naukowych na świecie pojawiają się nowe pojęcia i nazwy nowych dyscyplin naukowych, takich jak neuropedagogika, neurodydaktyka lub neurobiologia edukacyjna, czy neuropsychologia edukacyjna. Niektórzy autorzy podkreślają, że są to różne nazwy jednej dyscypliny ${ }^{2}$, inni wskazują na rozbieżności w zakresie granic semantycznych każdej nazwy ${ }^{3}$. Sytuacja taka powoduje problemy w porozumieniu się zarówno wśród pracowników naukowych, jak i praktyków. Aby temu zaradzić, w USA, Wielkiej Brytanii i Kanadzie podjęto próby właściwego umiejscowienia nowych dyscyplin wśród istniejących już nauk. Niestety, w Polsce dotychczas nie pojawiły się publikacje dotyczące powyższego. Niniejszy artykuł jest próbą uporządkowania wiedzy z omawianego zakresu oraz przedstawienia autorskiej koncepcji nazewnictwa nowych dziedzin na gruncie polskim w odniesieniu do istniejących dyscyplin naukowych.

\section{Z historii badań nad biologicznymi uwarunkowaniami edukacji}

Poszukiwania biologicznych uwarunkowań procesu uczenia się trwają już od czasów starożytnych. Jednakże, poważne dyskusje naukowe dotyczące powyższego zaczęły intensywnie rozwijać dopiero w drugiej połowie XIX wieku. Początkowo polegały na poszukiwaniu zależności między szeroko rozumianymi uwarunkowaniami biologicznymi a efektywnością uczenia się.

Franciszek Galton (brytyjski podróżnik, przyrodnik, antropolog, eugenik, wynalazca, meteorolog, pisarz, lekarz, psychometra i statystyk, prekursor badań nad inteligencją) w 1869 roku podjął publiczną dyskusję nad tym, co ma silniejszy wpływ na proces uczenia się: uwarunkowania biologiczne czy wychowanie. W tym samym czasie powstała teoria tak zwanego Efektu Baldwina (nazwa od amerykańskiego filozofa i psychologa Jamesa Marka Bald-

-Jones, Introducing Neuroeducational Research: Neuroscience, Education and the Brain from Contexts to Practice, Abingdon 2010; S.D. Sala, M. Anderson, Neuroscience in Education. The good, the bad, and the ugly, Oxford 2012; D. Mareschal, A. Tolmie, B. Butterworth, Educational Neuroscience, Blackwell 2013; E. Petlák, J. Zajacova, Rola mózgu w uczeniu się, Kraków 2010; J. Trnikova, E. Petlák, Neurodidaktika a vyucovanie, Einbeck 2010.

${ }^{2}$ Zob. T. Tokuhama-Espinosa, A BRIEF HISTORY OF THE SCIENCE OF LEARNING: Part 2 (1970s-present), 2011 [on line] http://education.jhu.edu/PD/newhorizons/Journals/Winter2011/Tokuhama5.

${ }^{3}$ Tamże. 
wina), która sugerowała, że skoro uczenie się stanowi warunek przetrwania gatunku, to umiejętność ta przekazywana jest w sposób biologiczny (poprzez geny $)^{4}$. Założenia te znalazły swoje odzwierciedlenie między innymi w badaniach Jeana Piageta (szwajcarskiego psychologa, biologa i epistemologa), który nie tylko określił cztery etapy rozwoju poznawczego, ale także podjął próbę ich biologicznego wyjaśnienia ${ }^{5}$.

W latach 50. XX wieku badaniem procesu uczenia się zajęli się głównie psycholodzy i biolodzy, którzy zaczęli analizować go w nawiązaniu do biologii komórki. W 1949 roku Donald Hebb (kanadyjski psycholog) założył istnienie związku między nauką o mózgu i uczeniem się. Przedstawił on koncepcję Ivana Pawłowa w odniesieniu do sieci neuronów. Hebb przyjął, że połączenie dwóch różnych bodźców tworzy nowe łącza neuronalne i w efekcie następuje nowa reakcja. Na podstawie tych założeń podjął również próbę wyjaśnienia większej skuteczności procesu uczenia się, organizowanego w atmosferze pozytywnych emocji. Dziś ta teoria jest między innymi podłożem badań nad plastycznością mózgu ${ }^{6}$. W 1958 roku Mark R. Rosenzweig (amerykański psycholog) i Marian C. Diamond (amerykańska profesor anatomii człowieka i neuroanatomii) opublikowali wyniki eksperymentów, które uwidoczniły rozrost neuronów (dendrytów) u szczurów pod wpływem procesu uczenia $\mathrm{się}^{7}$. Dwadzieścia lat później rosyjski psycholog Aleksander Łuria wykazał, że w wyżej wymienionym procesie w mózgu udział biorą różne systemy pamięciowe, a informacje mogą być kodowane w różnych "formatach" za pomocą różnych dróg nerwowych ${ }^{8}$.

W tym samym czasie zaczęła wyłaniać się nowa dyscyplina naukowa. W 1978 roku ukazały się dwie publikacje: Brain Research and Learning (Claycomb) i Education and The Brain (Chall, Mirsky). Ich autorzy podjęli próbę integracji neurologii i edukacji, ale jako nowej subdyscypliny ugruntowanej już neuropsychologii. Skupili się jednak na badaniach wyłącznie procesu uczenia się (learning), pomijając proces nauczania (teaching). Być może dlatego dyscyplina ta nie znalazła zbyt wielu zwolenników i nie zyskała takiego uznania, jak kształtujący się $\mathrm{w}$ tym samym czasie inny obszar interdyscyplinarnych badań zwany Mind, Brain and Education Science (MBE).

\footnotetext{
${ }^{4}$ J.M. Broughton, Piaget's Structural Developmental Psychology, Human Development, 1981, 24,5 .

${ }^{5}$ J. Piaget, Biology and knowledge. Chicago 1971; tenże, To understand is to invent: The future of education, New York 1976.

${ }^{6}$ T. Tokuhama-Espinosa, A BRIEF HISTORY OF THE SCIENCE OF LEARNING: Part 2 (1970s-present), 2011 [on line] http://education.jhu.edu/PD/newhorizons/Journals/Winter2011/Tokuhama5.

7 B.B Johansson, P.V. Belichenko, Environmental influence on neuronal and dendritic spine plasticity after permanent focal brain ischemia, Berlin - Heidelberg 2011.

8 A. Luria, J. Bruner, The mind of a mnemonist: A little book about a vast memory, Cambridge 2006.
} 
Za prekursorów MBE w literaturze przedmiotu uważa się naukowców amerykańskich. Jednakże, publikacje budujące teoretyczne podstawy tej dziedziny nauki pojawiały się od lat 70. XX wieku także $w$ wielu innych ośrodkach naukowych na całym świecie, jako jedna z konsekwencji intensywnego rozwoju metod obrazowania mózgu (rezonansu magnetycznego, funkcjonalnego rezonansu magnetycznego tomografii pozytronowo-emisyjnej), które umożliwiły uzyskiwanie danych biologicznych stanowiących potencjalne podłoże neuronalne procesu uczenia się. Michael Posner (psycholog z USA) jest autorem około 280 książek i artykułów o uwadze i pamięci. Swoje najwcześniejsze prace napisał w 1970 roku, a obecnie jego dzieła wnoszą istotny wkład w rozwój MBE. W USA w 1981 roku po raz pierwszy James Lee O’Dell użył pojęcia Mind, Brain and Education (MBE), w książce pod znamiennym tytułem: Neuroeducation: Brain Compatible Learning Strategies. Podkreślił w niej, że tylko zrozumienie neuronalnych mechanizmów procesów poznawczych pozwoli na zaprojektowanie prawdziwie efektywnych programów edukacji.

W tym samym czasie, w 1983 roku, pojawiły się kolejne dwie ważne publikacje, autorstwa amerykańskich psychologów, dotyczące omawianej tematyki: Frames of Mind Howarda Gardnera i Human Brain, Human Learning Leslie A. Hart. Gardner stworzył nową koncepcję inteligencji wielorakiej, wskazując pośrednio na umiejscowienie kilku jej rodzajów w określonych obszarach mózgu. Z kolei Hart podkreślił, że projektowanie doświadczeń edukacyjnych bez zrozumienia mózgu było jak projektowanie rękawic bez zrozumienia ludzkiej ręki. I to właśnie dzieło Harta jest powszechnie uważane za pierwszą publikację naukową z dziedziny neuroedukacji. Nazwa ta stanowiła kolejną próbę określenia istoty nowo powstającej dyscypliny. Obecnie, według niektórych autorów, neuroedukacja poprzez głębokie zrozumienie procesów leżących u podstaw ludzkiej świadomości, uczenia się i rozwoju przenosi wiedzę o rozwoju układu nerwowego do praktyki pedagogicznej9', przy czym zrozumienie zasad funkcjonowania mózgu ma istotny wpływ na sposób organizowania procesu edukacji (metody nauczania), ale jest mniej ważne w zakresie doboru treści programowych (podstawa programowa) ${ }^{10}$. Neuroedukacja nie proponuje zatem radykalnych zmian $\mathrm{w}$ obszarach treści kształcenia, ale raczej postuluje położenie nacisku na rozwój zdolności poznawczych istotnych dla procesu wychowania i nauczania oraz na organizowanie przestrzeni edukacyjnej wspierającej optymalne wykorzystanie poten-

${ }_{9}$ T. Tokuhama-Espinosa, Mind, Brain, and Education Science; D.A. Sousa, Mind, Brain, and Education: Neuroscience Implications for the Classroom (Leading Edge) (Leading Edge (Solution Tree), Hardcover 2010.

${ }^{10}$ S.J. Pickering, P. Howard-Jones, Educators' Views on the Role of Neuroscience in Education: Findings From a Study of UK and International Perspectives, Mind Brain adn Education, 2007, 1, 3, s. 109-113; L. Serpati, A.R. Loughan, Teacher Perceptions of NeuroEducation: A Mixed Methods Survey of Teachers in the United States, Mind Brain and Education, 2012, 6(3), s. 174-176. 
cjału mózgu uczniów. Z czasem pojęcie neuroedukacji zaczęto coraz częściej utożsamiać z bardziej popularną, wcześniej opisywaną dziedziną - MBE.

Działania w USA miały wpływ na zmiany w sposobie myślenia autorów europejskich. W 1988 roku Gerhard Preiss (profesor dydaktyki na Uniwersytecie we Fryburgu w Niemczech, specjalista w dziedzinie wczesnej edukacji matematycznej) rozpoczął badania nad neurobiologicznymi uwarunkowaniami procesu uczenia się. Wprowadził też pojęcie neurodydaktyki, uważając, iż osoby zajmujące się pedagogiką szkoły i ogólnie dydaktyką muszą pamiętać, że nauczanie i uczenie się oparte są na procesach mózgowych. Neurodydaktyka miała badać warunki optymalizacji procesu kształcenia i w założeniach Preissa stanowić nową gałąź teorii kształcenia. Jej przedstawiciele mieli podejmować próby budowania strategii nauczania i sposobów uczenia się, wykorzystując obiektywne wyniki badań mózgu. Od tego czasu pojęcie neurodydaktyki zaczęło stawać się przedmiotem dyskusji, często jako interfejs neurologii, dydaktyki, pedagogiki i psychologii ${ }^{11}$. $Z$ tego powodu niejednokrotnie używano go zamiennie z pojęciem neuropedagogiki czy naeuroedukacji. Po roku 2000 pojęcie „neurodydaktyki” zostało rozpowszechnione w Stanach Zjednoczonych Ameryki ${ }^{12}$.

Podsumowując, można zaznaczyć, że początki naukowych, interdyscyplinarnych, opublikowanych teorii dotyczących łączenia neurobiologii z procesem uczenia się sięgają XIX wieku, a ich prekursorami byli w większości amerykańscy psycholodzy z różnych ośrodków naukowych. Jednocześnie, w zależności od miejsca badań, nowa dyscyplina była nazywana neuropsychologią edukacyjną, MBE, neuronaukami edukacyjnymi, czy rzadziej neuroedukacją. W Europie rozpowszechniło się zaś pojęcie neurodydaktyki, utożsamianej z neuropedagogiką, a współcześnie również z MBE.

\section{Mózg i edukacja współcześnie}

W ostatnich latach pojawiło się wiele publikacji, których autorzy podejmowali próby syntezy dotychczas prowadzonych badań w zakresie neuronalnych odniesień do procesu edukacji ${ }^{13}$, a także stworzyli wiele modeli dydaktycznych

${ }^{11}$ S. Gauggel, M. Herrmann, Handbuch der Neuro- und Biopsychologie, Göttingen 2006; M. Spitzer, Deutscher Taschenbuch Verlag, 2006; I. L. Sonnier, J. Goldsmith, The pedagogy of neuroeducation: Achieving holistic education [w:] Methods and Techniques of Holistic Education, red. I. Sonnier, Springfield 2005; M. Spitzer, Lernen. Gehirnforschung und die Schule des Lebens. Korr. Nachdr. Heidelberg, Berlin 2003; tenże, Vorsicht Bildschirm! Elektronische Medien, Gehirnentwicklung, Gesundheit und Gesellschaft, Stuttgart - Düsseldorf - Leipzig 2005; G. Preiss, Neurodidaktik. Theoretische und praktische Beiträge, Herbolzheim 1998.

12 H. Gardner, Quandaries for Neuroeducators, Mind Brain and Education, 2008, 2(4), s. 165-169.

${ }^{13}$ L. Meltzer, Executive Function in Education From Theory to Practice, New York 2007; E. Frauenfelder, F. Santoianni, Le scienze bioeducative. Prospettive di ricerca, Liguori - Napoli 2002; 
opracowanych na podstawie nowych teorii ${ }^{14}$. Inspiracji z tego zakresu można doszukiwać się także w takich koncepcjach, jak A.Ş. Neill w Summerhill, szkoła Sudbury, Reggio Emilia, Montessori, International Baccalaureate i Steiner-Waldorf ${ }^{15}$. Oznacza to, że przez długi czas w wielu ośrodkach naukowych jednocześnie były podejmowane próby analizowania neurobiologicznych odniesień do procesu uczenia się i nauczania. Funkcjonowały już pojęcia neuropedagogiki, neuropsychologii edukacyjnej, neurobiologii edukacji, neurodydaktyki i MBE. Wobec wielości nazw i konieczności usytuowania rozwijającej się nowej dziedziny, naukowcy i praktycy podjęli próby ich systematyzacji.

W XXI wieku w czasopismach popularnonaukowych w Stanach Zjednoczonych oraz Europie Zachodniej zaczęto publikować wiele artykułów o charakterze komercyjnym, często przygotowywanych przez praktyków. Wśród nich można odnaleźć schematy dotyczące uporządkowania nowego nazewnictwa. Poniżej zaprezentowano najbardziej powszechny z nich.

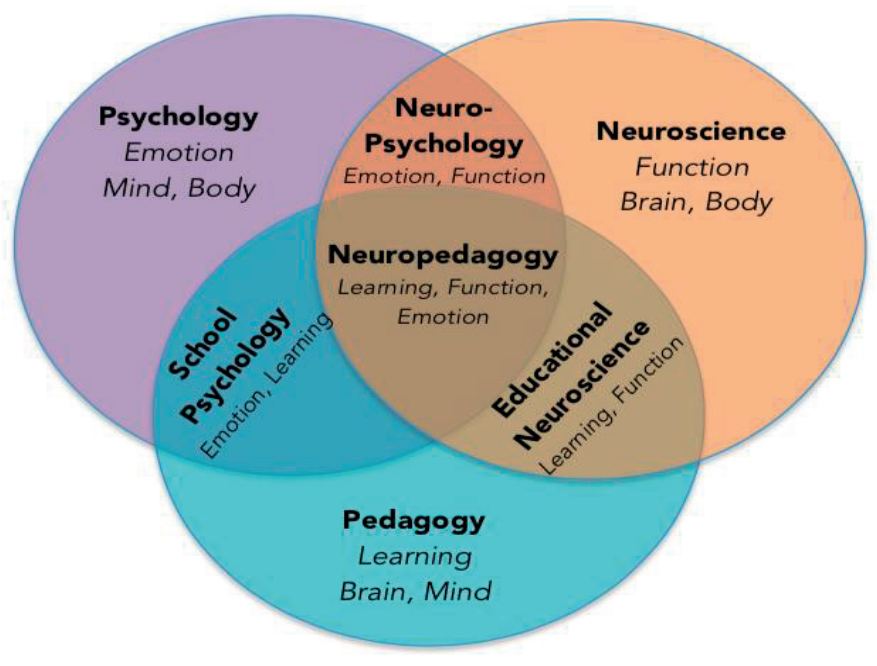

Ryc. 1. Schematyczne ujęcie interdyscyplinarnej współpracy trzech dyscyplin źródło: S. Naegele, The Fundaments of Neuropedagogy, Execu-Sensory and Neuropedagogy, Educational Consulting Services, 2015: (https:/ / esnpconsulting.com/professional-development/neuropedagogy-methodology/)

D.R. Olson, N. Torrance, Modes of thought: Explorations in culture and cognition, New York 1996; S.L. Friedman, K.A. Klivington, R.W. Peterson, The Brain, Cognition, and Education, 1986; F. Santoianni, C. Sabatano, Brain Development in Learning Environments. Embodied and Perceptual Advancements, Cambridge 2007.

${ }^{14}$ Por. R. Caine, G. Caine, Natural Learning for a connected World: Education, Technology and the Human Brain, New York 2011; D.A. Sousa, Mind, Brain, and Education; E. Jensen, Brain-based learning: The new paradigm of teaching, Thousand Oaks 2008.

${ }_{15}$ T.J. Carew, S.H. Magsamen, Neuroscience and education: An ideal partnership for producing evidence-based solutions to guide 21st century learning, Neuron, 2010, 67(5), s. 685-688. 
Jego popularyzatorka - Sara Naegele (pedagog specjalny, terapeuta zajęciowy) - sugeruje, że w centrum zainteresowania powinna znajdować się dyscyplina zwana neuropedagogiką, rozumiana jako interdyscyplinarne pole badań z zakresu: neuronauk, pedagogiki i psychologii, mające na celu ulepszanie starych i tworzenie nowych metod oraz programów nauczania, dostosowanych do mózgowych możliwości ucznia (w odróżnieniu od neuroedukacji, która skupiała się jedynie na dzieciach o specjalnych potrzebach edukacyjnych). Przedmiotem zainteresowania neuropedagogiki są emocje (rozumiane w ujęciu Teorii Inteligencji Wielorakich jako Inteligencja Emocjonalna), proces uczenia się dziecka i funkcje wykonawcze ${ }^{16}$ (umożliwiają organizowanie i przetwarzanie informacji, rozwiązywanie problemów z wykorzystaniem nabytych informacji oraz posiadanego doświadczenia). Wśród interdyscyplinarnych dziedzin badawczych zostały uwzględnione także: neuropsychologia, psychologia szkoły oraz neuronauki edukacyjne ${ }^{17}$.

Inną próbą usystematyzowania nowych pojęć może być schemat ilustrujący teorię multidyscyplinarnej dziedziny, propagowaną między innymi przez pedagog Danę Nakagawę (ryc. 2).

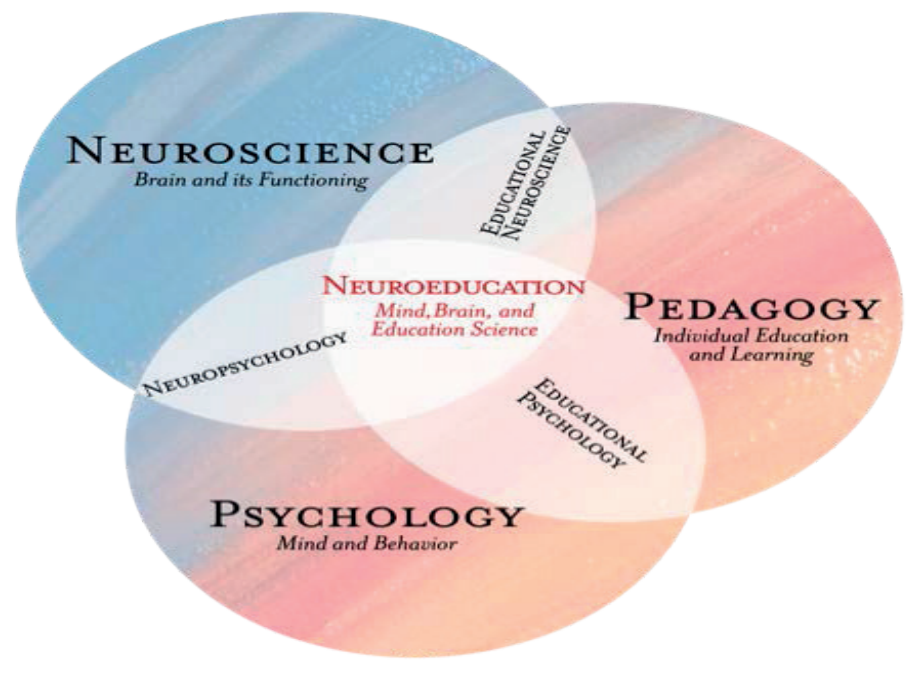

Ryc. 2. Schematyczne ujęcie neuroedukacji

źródło: http://education.jhu.edu/PD/newhorizons/Journals/Winter2011/Tokuhama1

${ }^{16}$ Zob. też K. Jodzio, Neuropsychologia intencjonalnego działania. Koncepcje funkcji wykonawczych, Warszawa 2008.

17 Zob. J.A. Willis, The Neuroscience of Joyful Learning. Educational Leadership, Journal of the Association for Supervision and Curriculum Development, 2007, 64. On-line only through ASCD.org to Publications. 
Nakagawa skupiła się na kwestii efektywności działań nauczyciela. Założyła, że najbardziej efektywni nauczyciele planując szeroko rozumiane działania edukacyjne, czerpią informacje ze wszystkich tych trzech wyżej wymienionych dziedzin, czyli korzystają z dorobku MBE jako multidyscyplinarnego pola badań: neuropsychologii, psychologii edukacji i neurologii edukacji. Nakagawa uznała jednak, że MBE stanowi przedmiot, nie podmiot, zainteresowań nowej nauki, której zasadniczym celem jest polepszanie jakości pracy nauczyciela, dlatego można ją nazwać neuroedukacją ${ }^{18}$.

Interpretacja ta nie zyskała uznania wśród uczonych. Większą popularność zdobyła teoria fizyka i neurobiologa Hideaki Koizumi (1999) oraz pedagoga i psychologa Boby Samuels (2009), która stanowi obecnie jedną z podstaw traktowania MBE jako dyscypliny naukowej (ryc. 3).

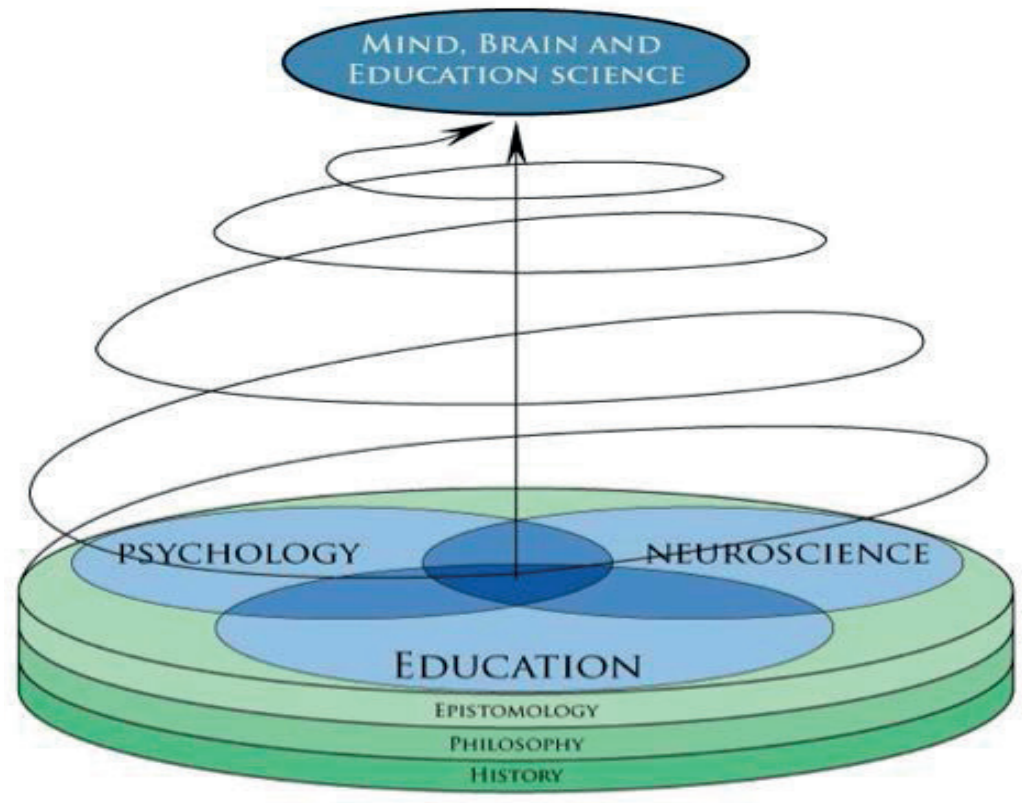

Ryc. 3. Schemat teoretycznych założeń MBE

źródło: T. Tokuhama-Episona 2010 na podstawie koncepcji badań interdyscyplinarnych Hideaki Koizumi (1999) i Boby Samuels (2009) [on line] http://education.jhu.edu/PD/newhorizons/ Journals/Winter2011/Tokuhama

18 T. Tokuhama-Esponosa, Why Mind, Brain, and Education Scienceis the "New" Brain-Based Education, 2008 [on line] http://education.jhu.edu/PD/newhorizons/Journals/Winter2011/ Tokuhama1. 
Teoria ta zakłada, że MBE stanowi pole interdyscyplinarnych badań z zakresu trzech dziedzin: pedagogiki (na schemacie poniżej nazwanej edukacją, co odzwierciedla obecny w wielu krajach trend do nieużywania pojęcia „pedagogika” jako określenia dyscypliny naukowej), psychologii i neuronauk - jako dyscyplin z ugruntowaną historią, filozofią i epistemologią. Założenia te zostały potwierdzone i uzupełnione $\mathrm{w}$ trakcie interdyscyplinarnej konferencji w Delphi, w 2005 roku. Zadanie ponad 30 specjalistów z dziedziny neurobiologii, psychologii i pedagogiki polegało wówczas na przyjrzeniu się dostępnej literaturze i uporządkowaniu wiedzy w zakresie nowo powstającej dziedziny. Na spotkaniu tym przyjęto nazwę Mind Brain and Education Science, która najtrafniej opisywała nową dyscyplinę, stanowiącą pole interdyscyplinarnej dyskusji przede wszystkim pedagogów, psychologów i przedstawicieli neuronauk (biologii, chemii, fizyki, czy medycyny). W trakcie licznych dyskusji wskazano, że specjaliści z zakresu MBE powinni zaakceptować różne korzenie historyczne trzech dyscyplin, co oznacza, że na przykład nauczyciele muszą zrozumieć, że psychologia i neurobiologia, choć mają inne cele, metody i procedury, niż te charakteryzujące edukację, to są równie przydatne do organizowania procesu uczenia się i nauczania. Podobnie psycholodzy praktykujący w nowej dyscyplinie muszą uznać, że informacje z zakresu neurologii i edukacji są równie cenne, pomimo różnic w metodologii. Neurolodzy zaś powinni nauczyć się na przykład doceniać znaczenie badań jakościowych. Bruno della Chiesa, Vanessa Christoph i Christina Hinton (2009) wskazali ponadto, że naukowcy praktykujący MBE muszą weryfikować hipotezy badawcze na podstawie metod dostępnych dla każdej dziedziny i otrzymane wyniki uznawać za ważne $\mathrm{w}$ takim samym zakresie. Takie podejście podkreśla również sama nazwa dyscypliny, która sugeruje trójdrożny sposób przepływu informacji. Oznacza to, że jeśli jakieś wyniki mają zostać przyjęte w nowej dyscyplinie, pedagodzy, psycholodzy i neurolodzy muszą potwierdzić swoje hipotezy nie tylko w swoich dyscyplinach, ale także w dwóch pozostałych ${ }^{19}$.

Można zatem uznać, że w opinii większości naukowców obecnie nazwa MBE najtrafniej definiuje nowe pole badań i nie jest słuszne używanie jej zamiennie z pojęciami: neuroedukacja, neuropedagogika, neurodydaktyka, czy neuropsychologia edukacyjna, ponieważ ich zakres znaczeniowy nie jest tożsamy. W sposób przejrzysty ilustruje to rycina 4.

${ }^{19}$ K.W. Fischer i in., Why mind, brain and education? Why now? Mind Braind and Education, 2002, 1(1), s. 1-2. 


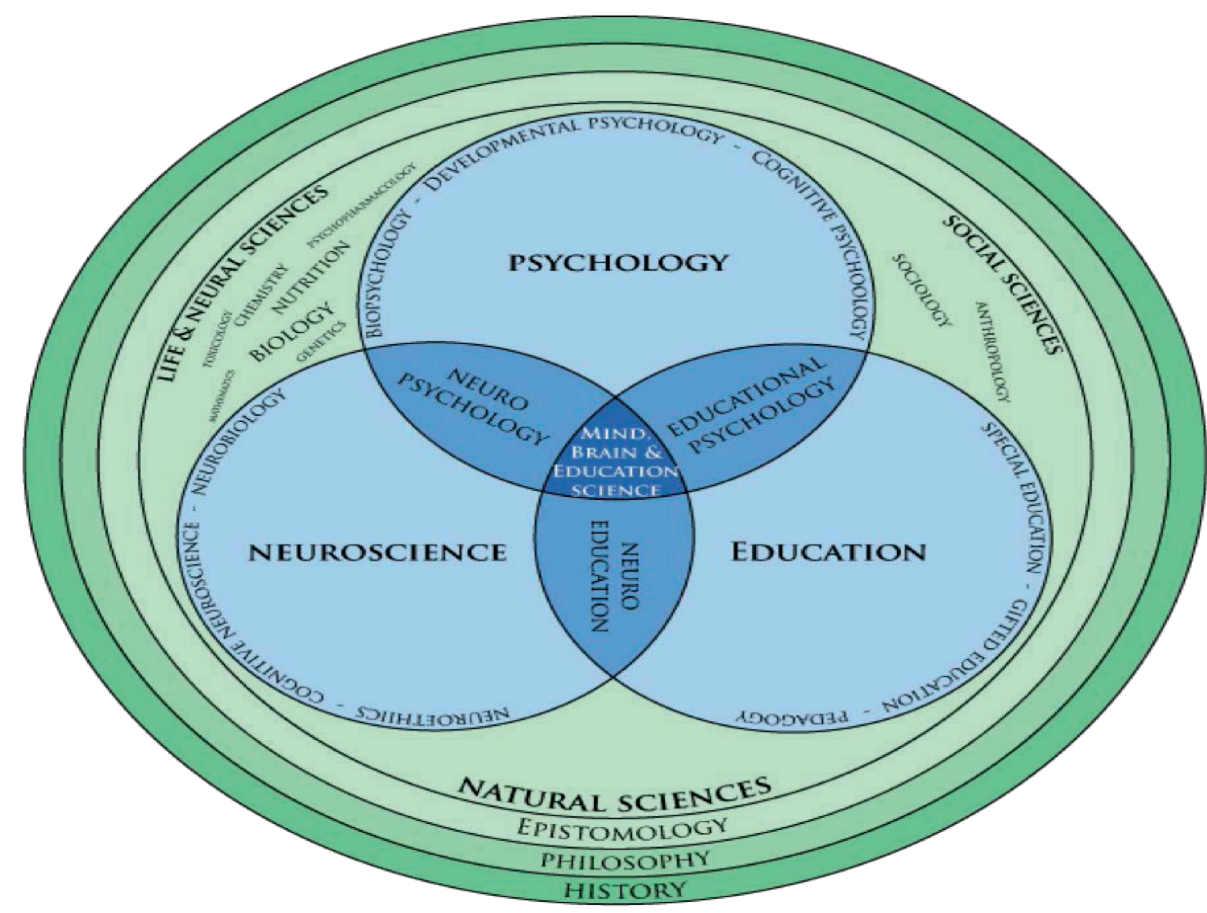

Ryc. 4. Umiejscowienie nowych dyscyplin w systemie nauk źródto: http://education.jhu.edu/PD/newhorizons/Journals/Winter2011/Tokuhama1

\section{Neuropedagogika jako nowe pole badań w systemie współczesnych nauk}

W dostępnej obecnie literaturze zagranicznej upowszechniła się nazwa MBE jako określenie pola interdyscyplinarnych badań z zakresu pedagogiki (edukacji), psychologii i neuronauk. Jednocześnie naukowcy dookreślili również miejsce innych nowo powstających dziedzin, takich jak neuroedukacja, która ma stanowić dziedzinę interdyscyplinarnych badań pedagogicznych i neurobiologicznych. Opierając się na powyższych, można wnioskować, że przedmiot badań neuroedukacji jest tożsamy z przedmiotem badań pedagogiki, ale jego interpretacja odnosi się do kontekstu neurobiologicznego, zaś postawione hipotezy wymagają potwierdzenia metodami dostępnymi pedagogom i neurobiologom.

W zagranicznych publikacjach naukowych kwestia nazewnictwa nowych dyscyplin wydaje się nie budzić już wątpliwości, ale na gruncie polskim omawiana tematyka nadal wymaga pojęciowego doprecyzowania. W licz- 
nych wydawnictwach naukowych i popularnonaukowych nadal bowiem uwidacznia się problem braku ujednoliconego nazewnictwa, adekwatnego do specyfiki języka polskiego i publikacji naukowych polskich uczonych. Obecne nieścisłości powodują chaos i mogą skutkować mniejszym obiektywizmem, precyzją oraz trafnością w prowadzonych badaniach i publikacjach. Problem ten dotyczy kluczowych dla nowej dyscypliny pojęć, to jest: pedagogiki i edukacji.

W świetle polskich publikacji, nie są to pojęcia tożsame. Pierwsze z nich oznacza dyscyplinę naukową, posiadającą przedmiot badań, metodologię i własną terminologię, drugie - określa przedmiot badań tejże dyscypliny. Ze względu na ograniczone ramy tego artykułu, skupię się na definicji pojęcia „edukacja” - zapożyczonego z krajów anglosaskich i tamże zastępującego "pedagogikę".

Według polskiego dydaktyka i pedagoga - Bogusława Niemierki, działania edukacyjne oddziałują na procesy emocjonalno-edukacyjne oraz poznawcze. Pierwsze dotyczą uczuć, motywów, postaw i wartości, a drugie widomości, umiejętności i sprawności działań ucznia. Zależnie od roli tych aspektów w projektowaniu, wykonaniu i ocenianiu wyników działania edukacyjnego możemy wyróżnić: wychowanie (edukację emocjonalną), nauczanie (edukację poznawczą), kształcenie (edukację zrównoważoną) ${ }^{20}$. Edukacja w tej koncepcji jest pojęciem najszerszym, obejmującym wszystkie wyżej wymienione działania - rycina 5.

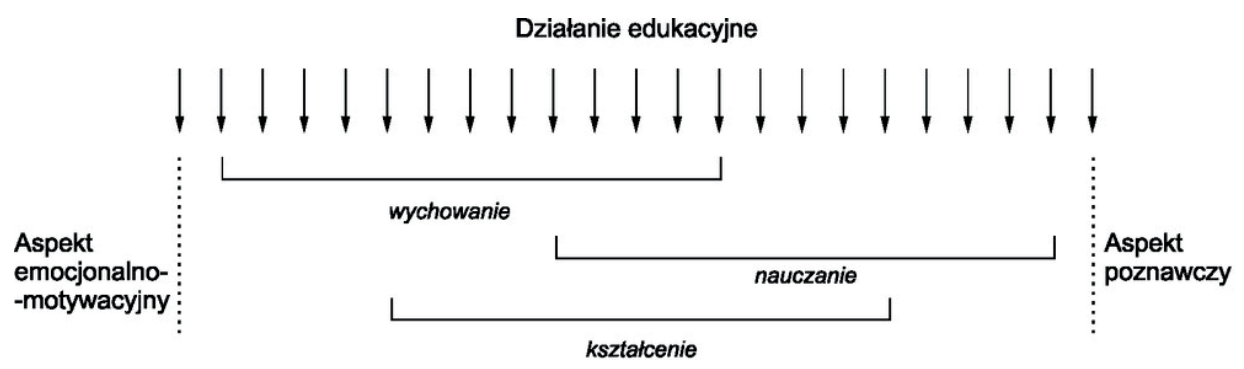

Ryc. 5. Schematyczne ujęcie działań edukacyjnych źródło: B. Niemierko, Diagnostyka edukacyjna, Warszawa 2009, s. 35

Badaniem edukacji zajmuje się pedagogika. Zatem, nie są to pojęcia tożsame. Wydaje się, że zarówno w Polsce, jak i za granicą, do miana dyscypliny/ subdyscypliny naukowej mogłaby aspirować neuropedagogika, natomiast

${ }^{20}$ B. Niemierko, Diagnostyka edukacyjna, Warszawa 2009, s. 22. 
pojęć edukacja czy neuroedukacja należałoby używać do określenia interdyscyplinarnego pola badań.

Ze względu na różnorodne szczegółowe przedmioty badań, w neuropedagogice można wyróżnić subdyscyplinę zwaną neurodydaktyką. Jej przedstawiciele powinni zajmować się tematyką nauczania i uczenia się w kontekście badań nad mózgiem, dokonując analizy metod kształcenia i programów nauczania w celu jak najlepszego dostosowania ich do możliwości neuronalnych dziecka czy dorosłego. Nie jest zatem zasadne używanie zamiennie pojęć neurodydaktyka oraz neuropedagogika, ponieważ zakres znaczeniowy pierwszego stanowi część drugiego. Neuroedukacją można zaś określić przedmiot badań (pole badań) zarówno neuropedagogiki, jak i neurodydaktyki, ale także innych dyscyplin zainteresowanych nauczaniem, wychowaniem i kształceniem.

\section{Podsumowanie}

Filar nowych przestrzeni badawczych stanowią trzy dyscypliny: pedagogika, psychologia i neuronauki. Każda z nich ma swój przedmiot badań, metodologię oraz terminologię. Wobec intensywnego rozwoju badań nad mózgiem, psycholodzy zaczęli poszukiwać przyczyn zaburzeń funkcjonowania poznawczego i emocjonalnego człowieka w funkcjonowaniu centralnego układu nerwowego. Przedstawiciele nowej dziedziny - neuropsychologii z czasem zaczęli się specjalizować w jej różnych bardziej szczegółowych aspektach (np. neuropsychologia dziecka, kliniczna, rozwojowa). Pojawiło się także zainteresowanie procesem uczenia się dzieci (neuropsychologia edukacyjna).

Rozwój metod obrazowania mózgu, a także wzrost znaczenia neuropsychologii spowodował, że z dostępnych wyników badań zaczęli korzystać przedstawiciele pedagogiki, przenosząc je między innymi na kanwę praktyki szkolnej. Działania te stanowiły początek badań z zakresu neuropedagogiki - dyscypliny/subdyscypliny, która ma poszukiwać neurobiologicznych podstaw i uwarunkowań organizowania efektywnego procesu edukacji (rozumianego jak nauczanie, wychowanie i kształcenie). Neuropedagogika nie jest także tożsama z popularną MBE. Łączy bowiem jedynie dwie dyscypliny (neuronauki i pedagogikę), uznając je za równoważne i zakładając konieczność weryfikowania hipotez badawczych w obu tych dziedzinach.

Jedną z subdyscyplin neuropedagogiki jest neurodydaktyka - nowa gałąź teorii kształcenia, przedstawiciele której powinni podejmować próby budowania strategii nauczania opierając się na wynikach badań nad mózgiem. 
Neurodydaktyka nie jest zatem tożsama z neuropedagogiką. Jest jej częścią, jak dydaktyka - pedagogiki.

Dyscypliną, która łączy pedagogikę, psychologię i neuronauki jest Mind, Brain and Education Science. W piśmiennictwie polskim nazwa ta nie cieszy się popularnością i jest trudna do praktycznego wykorzystania, chociażby w odniesieniu do programów studiów. Tłumaczenie dosłowne: „Umysł, Mózg i Edukacja" nie zyskało dotychczas uznania wśród polskich naukowców. W opinii autorki niniejszego artykułu, w polskiej terminologii należy upowszechnić nazwę amerykańską (MBE) lub poszukać jej polskiego odpowiednika. Być może nową dyscyplinę można by nazwać neuropsychoedukacją. Jednoczłonowa nazwa sugeruje ścisłe połączenie trzech dyscyplin i ukierunkowanie ich na proces edukacji, jako element je łączący. Jeśli pod pojęciem edukacji będziemy rozumieć procesy nauczania i kształcenia połączone $\mathrm{z}$ wychowaniem, to poprzez umiejscowienie ich $\mathrm{w}$ uwarunkowaniach psychologicznych i neurobiologicznych otrzymamy sugestie jednej z wyżej wymienionych nazw. Powyższe rozważania można ująć w schemat, który prezentuje rycina 6 .

Tematyka związana z neuropedagogiką wymaga dalszej analizy i zorganizowania interdyscyplinarnego sympozjum specjalistów z dziedziny pedagogiki i neurobiologii, którzy nie tylko dokonaliby analizy dotychczasowej literatury, ale podjęliby próbę sprecyzowania założeń neuropedagogiki jako dyscypliny badawczej.

Rozwój nowej dziedziny naukowej jest istotny w dobie postępu technologicznego, dotyczącego nie tylko metod obrazowania mózgu. Neuropedagogika może mieć znaczący udział w rozwiązaniu problemów w procesie edukacji, jakie mają tak zwane dzieci Sieci. Ich mózgi funkcjonują w specyficzny sposób, ponieważ zostały ukształtowane pod wpływem innych bodźców niż mózgi ich rodziców. Proces kształcenia tych dzieci powinien być zatem organizowany inaczej niż ich starszych kolegów. Zmiany miałyby dotyczyć nie tyle treści kształcenia, co raczej - metod i programów. Cenną informacją dla nauczycieli byłyby na przykład wyniki badań dotyczące kwestii, czy cyfryzacja przedszkoli i szkół podstawowych na poziomie edukacji wczesnoszkolnej przyczyni się do polepszenia wyników dzieci w perspektywie długofalowej, czy raczej do ich pogorszenia ${ }^{21}$.

Stanowi to jedno w wielu zadań między innymi dla neuropedagogów. Jednakże, pierwsze z nich dotyczy umiejscowienia tej dyscypliny wśród innych obszarów badawczych i przygotowania rzetelnych założeń teoretycznych (dotyczących przedmiotu badań, metodologii, terminologii), koniecznych do konstruowania i standaryzacji narzędzi badawczych.

${ }^{21}$ M. Chojak, Neuropedagogika, neuroedukacja i neurodydaktyka. Mity i fakty, Warszawa 2019. 

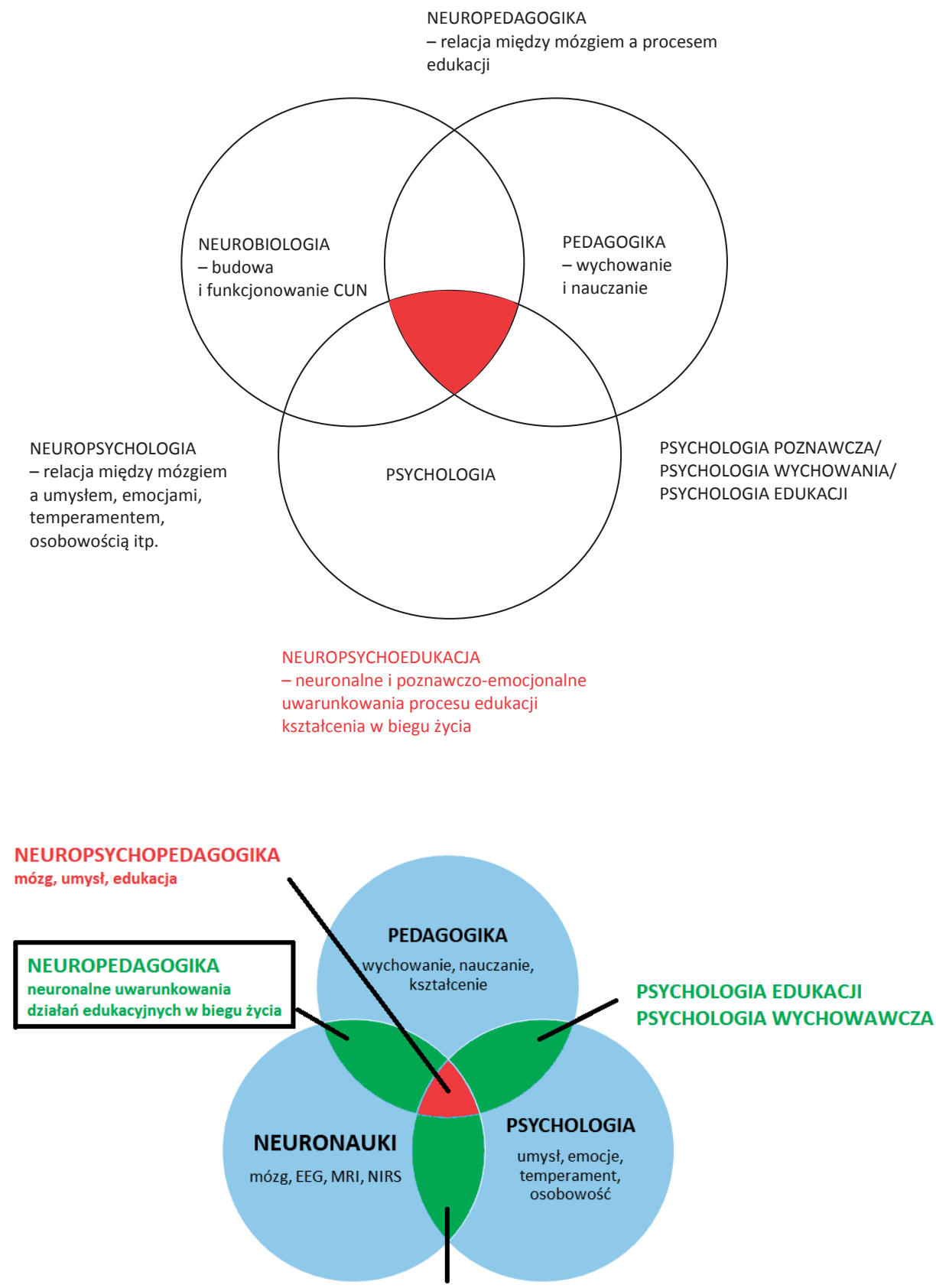

NEUROPSYCHOLOGIA

Ryc. 6. Schemat relacji między poszczególnymi neurodyscyplinami naukowymi 


\section{BIBLIOGRAFIA}

Brain-Based Learning: The Neurological Findings About the Human Brain that Every Teacher Should Know to be Effective [on line] http://globadvantage.ipleiria.pt/files/2011/06/ working_paper-77_globadvantage.pdf

Broughton J.M., Piaget's Structural Developmental Psychology, Human Development, 1981, 24,5 .

Caine R., Caine G., Natural Learning for a Connected World: Education, Technology and the Human Brain, Teachers College Press, New York 2011.

Carew T.J., Magsamen S.H., Neuroscience and education: An ideal partnership for producing evidence-based solutions to guide 21st century learning, Neuron, 2010, 67(5).

Chojak M., Neuropedagogika, neuroedukacja i neurodydaktyka. Mity i fakty, Wydawnictwo Difin, Warszawa 2019.

Fischer K.W., Daniel D.B., Immordino-Yang M.H., Stern E., Battro A., Why mind, brain and education? Why now? Mind Braind and Education, 2002, 1(1).

Frauenfelder E., Santoianni F., Le scienze bioeducative. Prospettive di ricerca, Liguori, Napoli 2002.

Friedman S.L., Klivington K.A., Peterson R.W., The Brain, Cognition, and Education, Academic Press, New York 1986.

Gardner H., Quandaries for Neuroeducators, Mind Brain and Education, 2008, 2(4).

Gauggel S., Herrmann M., Handbuch der Neuro- und Biopsychologie, Hogrefe Verlag, Göttingen 2006.

Goswami U., Principles of Learning, Implications for Teaching: A Cognitive Neuroscience Perspective, Journal of Philosophy of Education, 2008, 42, 3-4.

Howard-Jones P., Introducing Neuroeducational Research: Neuroscience, Education and the Brain from Contexts to Practice, Routledge, Abingdon 2010.

Jensen E., Brain-based learning: The new paradigm of teaching, Thousand Oaks, CA: Corwin 2008.

Jodzio K., Neuropsychologia intencjonalnego działania. Koncepcje funkcji wykonawczych, Wydawnictwo Naukowe Scholar, Warszawa 2008.

Johansson B.B., Belichenko P.V., Environmental influence on neuronal and dendritic spine plasticity after permanent focal brain ischemia, Springer, Berlin - Heidelberg 2011.

Luria A., Bruner J., The mind of a mnemonist: A little book about a vast memory, Cambridge Mass 2006 (oryginalna praca została opublikowana w 1968 roku).

Mareschal D., Tolmie A., Butterworth B., Educational Neuroscience, Wiley-Blackwell, London 2013.

Meltzer L., Executive Function in Education From Theory to Practice, The Guilford Press, New York 2007.

Naegele S., The Fundaments of Neuropedagogy, Execu-Sensory and Neuropedagogy, Educational Consulting Services, 2015: (https:/ / esnpconsulting.com/professional-development/ neuropedagogy-methodology/)

Niemierko B., Diagnostyka edukacyjna, Wydawnictwo Naukowe PWN, Warszawa 2009.

Olson D.R., Torrance N., Modes of thought: Explorations in culture and cognition, Cambridge University Press, New York 1996.

Petlák E., Zajacova J., Rola mózgu w uczeniu się, Wydawnictwo Petrus, Kraków 2010.

Piaget J., Biology and knowledge, University of Chicago Press, Chicago 1971.

Piaget J., To understand is to invent: The future of education, Macmillan, New York 1976. 
Pickering S.J., Howard-Jones P., Educators' Views on the Role of Neuroscience in Education: Findings From a Study of UK and International Perspectives, Mind Brain and Education, $2007,1,3$.

Preiss G., Neurodidaktik. Theoretische und praktische Beiträge, Herbolzheim: Centaurus 1998.

Sala S.D., Anderson M., Neuroscience in Education. The good, the bad, and the ugly, Oxford University Press, Oxford 2012.

Santoianni F., Sabatano C., Brain Development in Learning Environments. Embodied and Perceptual Advancements, Cambridge Scholars Press, Cambridge 2007.

Serpati L., Loughan A.R., Teacher Perceptions of NeuroEducation: A Mixed Methods Survey of Teachers in the United States, Mind Brain and Education, 2012, 6(3).

Sonnier I.L., Goldsmith J., The pedagogy of neuroeducation: Achieving holistic education, [w:] Methods and Techniques of Holistic Education, red. I. Sonnier, Illinois State Historical, Springfield 2005.

Sousa D.A., Mind, Brain, and Education: Neuroscience Implications for the Classroom (Leading Edge) (Leading Edge (Solution Tree), Hardcover, Bloomington 2010.

Spitzer M., Deutscher Taschenbuch Verlag, München, Heidelberg 2006.

Spitzer M., Lernen. Gehirnforschung und die Schule des Lebens. Korr. Nachdr. Heidelberg, München, Berlin 2003.

Spitzer M., Vorsicht Bildschirm! Elektronische Medien, Gehirnentwicklung, Gesundheit und Gesellschaft, Klett, Stuttgart - Düsseldorf - Leipzig 2005.

Tokuhama-Espinosa T., Mind, Brain, and Education Science: The new brain-based learning, Columbia University Teachers College Press, New York 2010.

Tokuhama-Espinosa T., The new science of teaching and learning: Using the best of mind, brain, and education science in the classroom, Columbia University Teachers College Press, New York 2010.

Tokuhama-Esponosa T., Why Mind, Brain, and Education Scienceis the "New" Brain-Based Education, 2008 [on line] http://education.jhu.edu/PD/newhorizons/Journals/Winter2011/Tokuhama1.

Tokuhama-Espinosa T., A BRIEF HISTORY OF THE SCIENCE OF LEARNING: Part 2 (1970s-present), 2011 [on line] http://education.jhu.edu/PD/newhorizons/Journals/Winter2011/Tokuhama5.

Trnikova J., Petlak E., Neurodidaktika a vyucovanie, Einbeck 2010.

Willis J.A., The Neuroscience of Joyful Learning. Educational Leadership, Journal of the Association for Supervision and Curriculum Development, 2007, 64 [on-line] only through ASCD.org to Publications. 